\begin{tabular}{|c|c|}
\hline 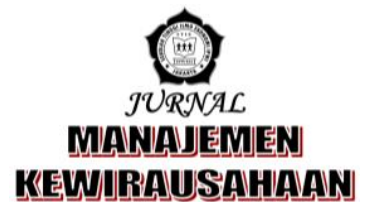 & $\begin{array}{r}\text { p-ISSN 1858-1048 } \\
\text { e-ISSN 2654-9247 } \\
\text { http://ejurnal.stieipwija.ac.id/index.php/jmk } \\
\text { DOI: http://dx.doi.org/10.33370/jmk.v17i1.390 } \\
\text { Jurnal Manajemen Kewirausahaan Vol. 17 No. 01 - Juni } 2020 \\
\text { Submit: 27 Apr 2020; Review: 15 Mei 2020; Publish: 30 Jun } 2020\end{array}$ \\
\hline
\end{tabular}

\title{
PENGARUH PELATIHAN, UPAH DAN MASA KERJA TERHADAP PRODUKTIVITAS DI PT SUPER STEEL KARAWANG
}

\section{(THE EFFECT OF TRAINING, WAGES AND WORK PERIOD ON PRODUCTIVITY AT PT SUPER STEEL KARAWANG)}

\author{
Oleh: \\ Ika Ramadhani'1), Sri Lestari Prasilowati'2), Suyanto ${ }^{3)}$ \\ Ika.dhani@gmail.com ${ }^{1}$, widiyantoterry@yahoo.com ${ }^{2}$, suyanto.ipwija@gmail.com ${ }^{3)}$ \\ Sekolah Tinggi Ilmu Ekonomi IPWI Jakarta1,2)
}

\begin{abstract}
The research on the influence of job training, wages, and work period to the productivity of PT Super Steel Karawang aim to find out whether effect on the productivity of employees of PT Super Steel Karawang as a basis for company decision making in conducting training activities, determining wages, and establishing working period policies to increasing company's productivity in general. This research method consists of qualitative data with data collection techniques using a questionnaire sample of 201 employees of PT Super Steel Karawang taken with the Slovin formula and then tested its effect with the multiple linear regression techniques with classical testing. There are no autocorrelation, heteroscedasticity, and multicollinearity assumptions from the test result. The results of the questionnaire study of each indicator proved to be valid and reliable with the multiple linear regression assumptions that each of them had fulfilled. The conclusion of this study shows that there is an influence of training and working period on productivity, but no effect of wage on productivity with the regression models.
\end{abstract}

Keywords: Productivity, Training, Wages, Work Period, Multiple Linear Regressions

\begin{abstract}
ABSTRAK
Penelitian pengaruh pelatihan kerja, upah, dan masa kerja terhadap produktivitas karyawan PT Super Steel Karawang bertujuan untuk mengetahui apakah ada pengaruhnya terhadap produktivitas karyawan PT Super Steel Karawang sebagai dasar pengambilan keputusan perusahaan dalam melakukan aktifitas pelatihan, penentuan upah, dan kebijakan masa kerja karyawan agar produktivitas perusahaan dapat meningkat secara umum. Metode penelitian ini berupa data kualitatif dengan teknik pengumpulan data menggunakan sebaran kuesioner sampel sebanyak 201 karyawan PT Super Steel Karawang diambil dengan rumus Slovin, kemudian diuji pengaruhnya dengan teknik regresi linier berganda dengan pengujian asumsi klasik normalitas, autokorelasi, heteroskedastisitas, dan multikolinieritas agar dapat ditunjukan besaran pengaruhnya. Hasil penelitian kuesioner masing-masing indikator terbukti valid dan reliabel dengan asumsi regresi linier berganda masing-masing sudah terpenuhi. Kesimpulan dari penelitian ini menunjukan adanya pengaruh pelatihan dan masa kerja pada produktivitas, namun hasil penelitian upah tidak adanya pengaruh pada produktivitas dengan model regresi.
\end{abstract}

Kata Kunci: Produktivitas, Pelatihan, Upah, Masa Kerja, Regresi Linier Berganda

Jurnal Manajemen Kewirausahaan Vol. 17 No. 01 - Juni 2020

LP2M Sekolah Tinggi Ilmu Ekonomi IPWI Jakarta 


\section{PENDAHULUAN}

Sumber daya manusia (SDM) adalah potensi terbesar negara Indonesia upaya memajukan bangsa ini. Pengelolaan SDM perlu diperhatikan jika ingin menghasilkan SDM yang berkualitas dan mampu bersaing guna meningkatkan produktivitas yang baik dan relevan. Beberapa penelitian banyak melakukan riset untuk pengelolaan sumber daya manusia sendiri salah satu indikatornya dengan mengadakan pelatihan peningkatan pengalaman kerja dan upah yang diterima, untuk dampak produktivitasnya meningkat. Dalam penelitian-penelitian sebelumnya banyak upaya untuk melihat faktorfaktor apa saja yang mampu meningkatkan produktivitas, sehingga banyak hal yang perlu dipelajari dan dibuktikan secara empiris mengenai produktivitas SDM.

Produktivitas kerja dalam suatu negara atau perusahaan merupakan penunjang keberhasilan suatu pengelolaan SDM di suatu wilayah tersebut. Menurut Herjanto (2007), produktivitas merupakan suatu ukuran yang menyatakan bagaimana baiknya sumber daya diatur dan dimanfaatkan untuk mencapai hasil yang optimal. Produktivitas yang tinggi sangat menguntungkan semua pihak baik pengusaha, pemerintah daerah, dan bahkan pribadi dari karyawan itu sendiri. Pengertian produktivitas kerja berasal dari serapan bahasa Inggris, yaitu productivity yang diartikan ke dalam bahasa Indonesia memiliki arti menghasilkan. Dalam kenyataannya produktivitas juga bisa dikatakan perbandingan antara input dan output yang dihasilkan. Perkembangan produktivitas bulanan dapat dilihat dari gambar berikut ini.

Gambar 1

Perkembangan Produktivitas per-Bulan

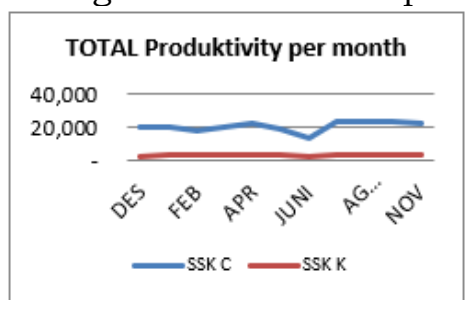

Di dalam beberapa kasus perhitungan produktivitas dipengaruhi oleh hasil output aktivitas produksi berbanding dengan inputan variabel. Sebagai contoh dari grafik produktivitas menandakan grafik yang cukup fluktuatif maka menarik untuk diteliti lebih lanjut faktor-faktor yang bisa mempengaruhi perubahan grafik produktivitas tersebut.

Peningkatan produktivitas dipengaruhi oleh banyak sekali faktorfaktornya baik faktor internal maupun faktor eksternal. Banyak permasalahan penurunan produktivitas di dunia industri yang saat ini terjadi sehingga perlunya pengujian secara ilmiah agar perusahaan-perusahaan potensial melakukan analisis perbaikan pada faktor-faktor yang mempengaruhi produktivitas secara keseluruhan.

Menurut Karima (2018) dalam jurnal publikasinya, pengaruh masa kerja, pelatihan, dan motivasi terhadap produktivitas kerja karyawan pada PT Bank Sulselbar cabang utama Makassar disebutkan faktor pelatihan dan masa kerja memiliki pengaruh yang cukup besar terhadap produktivitas. Serta dalam jurnal lain mengemukakan pendapat berbeda, hal ini menarik untuk ditinjau ulang dalam penelitian ini membuktikan hasil-hasil penelitian lain sebelumnya.

Pengaruh produktivitas di dunia industri akan melibatkan sedikitnya dua komponen eksternal maupun internal, dalam pembahasan ini diteliti ada tiga pengaruh yaitu pelatihan kerja, upah, dan masa kerja karyawan. Ketiga variabel itu akan diteliti di salah satu perusahaan otomotif di kawasan Jawa Barat yaitu PT Super Steel Karawang dengan pengambilan sampel di tiga perusahaannya sekaligus dalam kurun waktu satu tahun terakhir 2019.

Gambar 2

Survey Kepuasan Karyawan pada Pelatihan

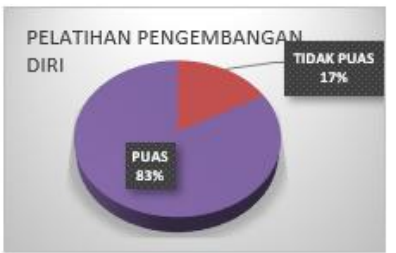


Hasil dari kepuasan pelatihan yang cukup besar di angka 83\% di PT Super Steel Karawang menunjukkan karyawan sangat puas dengan pelatihan yang sering dilakukan oleh pihak perusahaan.

Hasil penelitian ini nantinya dapat memperkuat hasil penelitian-penelitian terdahulu akan pemahaman pengaruh ketiga variabel dependennya yaitu pelatihan, upah, dan masa kerja yang akan diuji hipotesisnya dengan mendukung pengaruh positif ketiga variabel tersebut terhadap produktivitas karyawan PT Super Steel Karawang. Pengujian dilakukan dengan teknik regresi linier melalui program SPSS dan Minitab dengan komputasi sistematis untuk mencapai data yang signifikan dalam pengujian analisis data (Rosadi, 2005).

\section{TUJUAN PENELITIAN}

Tujuan penelitian dalam penelitian ini adalah guna mengetahui pengaruh variabel pelatihan, upah, dan masa kerja terhadap variabel produktivitas di PT Super Steel Karawang.

\section{TELAAH LITERATUR PENGEMBANGAN PROPOSISI Sumber Daya Manusia}

Sumber daya manusia adalah elemen terpenting dalam kemajuan suatu organisasi dan negara karena merupakan pembentuk elemen-elemen lainnya yang berkaitan dengan substansi teknologi, pangan, bahan baku hingga menciptakan sistem perubahan peradaban. Menurut Hariandja (2002), pada hakikatnya SDM berupa manusia yang dipekerjakan di sebuah organisasi sebagai penggerak, pemikir, dan perencana untuk mencapai tujuan organisasi itu.

Nawawi (2003) menjelaskan SDM dapat dibagi menjadi dua, yaitu pengertian mikro dan makro. Pengertian SDM secara mikro adalah individu yang bekerja dan menjadi anggota suatu perusahaan atau institusi dan biasa disebut sebagai karyawan, buruh, pegawai, pekerja, tenaga kerja, dan lain sebagainya. Sedangkan pengertian SDM secara makro adalah penduduk suatu negara yang sudah memasuki usia angkatan kerja, baik yang belum bekerja maupun yang sudah bekerja. Secara garis besar, pengertian sumber daya manusia adalah individu yang bekerja sebagai penggerak suatu organisasi, baik institusi maupun perusahaan dan berfungsi sebagai aset yang harus dilatih dan dikembangkan kemampuannya (Hariandja, 2002).

\section{Produktivitas Karyawan}

Produktivitas adalah "Ukuran seberapa baik sumber daya suatu negara digunakan untuk mencapai serangkaian hasil guna mencapai tingkat kinerja tertinggi dengan pengeluaran sumber daya yang paling sedikit, termasuk sumber daya manusia". Ini adalah definisi produktivitas yang disintesis, menurut penelitian Apriyani (2014).

Pada dasarnya produktivitas merupakan hasil keluaran atau output dari suatu kegiatan baik dalam jasa maupun material. Produktivitas memiliki tolak ukur yang berbeda-beda tergantung terhadap apa yang didapatnya atau diperoleh berdasarkan variabel-variabel pendukungnya.

Indikator produktivitas yang digunakan dalam penelitian ini berdasarkan pendapat Herjanto (2007), yaitu jumlah output yang dihasilkan berbanding dengan input yang diberikan, diantaranya kualitas pekerjaan, manajemen pekerjaan, dan kemauan optimalisasi diri.

\section{Pelatihan Kerja}

Pelatihan berasal dari bahasa Inggris training yang artinya pelatihan dalam kamus besar bahasa Inggris. Pelatihan adalah proses melatih, kegiatan, atau pekerjaan (KKBI, 2018). Berdasarkan Simamora (2004:273) dalam penelitian Kandou (2019) mengkaji dalam artikelnya, pelatihan dan pengembangan adalah dua istilah yang kadang-kadang digunakan secara bersama-sama maupun secara bergantian. Pelatihan (training) mengandung maksud untuk menambah 
dan meningkatkan pengetahuan dan keterampilan serta mengubah sikap atau perilaku karyawan ke arah yang lebih produktif. Pengembangan (development) dapat diasosiasikan dengan kebutuhan masa depan karyawan dan organisasi perusahaan.

Pelatihan dan pengembangan mempunyai manfaat pada karier jangka panjang karyawan, untuk menghadapi tanggung jawab yang lebih besar di masa yang akan datang. Simamora (2004:273-274) mengatakan pelatihan dan pengembangan ditujukan untuk mempertahankan dan meningkatkan prestasi kerja para karyawan. Pelatihan ditujukan untuk meningkatkan prestasi kerja saat ini, sedangkan pengembangan ditujukan untuk meningkatkan prestasi kerja saat ini dan masa yang akan datang. Pelatihan diarahkan untuk membantu karyawan melakukan pekerjaan saat ini secara lebih baik.

Indikator pelatihan dalam penelitian ini dengan dasar menurut Mangkunegara (2011:57) adalah metode pelatihan, penyampaian instruktur pelatihan dan fasilitas pelatihan.

\section{Upah}

Upah adalah pendapatan yang diterima tenaga kerja dalam bentuk uang, yang mencakup bukan hanya komponen upah atau gaji, tetapi juga lembur dan tunjangan yang diterima secara rutin atau reguler (tunjangan transport, uang makan dan tunjangan lainnya sejauh diterima dalam bentuk uang), tidak termasuk Tunjangan Hari Raya (THR), tunjangan bersifat tahunan, kuartalan, tunjangan-tunjangan lain yang bersifat tidak rutin dan tunjangan dalam bentuk natural (BPS, 2008).

Menurut Soedjardi (2008), upah yang diterima karyawan/buruh sangatlah berarti bagi kelangsungan hidup mereka dalam pemenuhan kebutuhan sehari-hari, karena dengan penerimaan upah seseorang dapat mewujudkan impian cita-citanya dan sekaligus juga dalam rangka meningkatkan taraf hidup yang layak bagi kemanusiaan. Kemampuan dan keahlian yang dimiliki seseorang sangatlah mempengaruhi upah.
Definisi lain dalam jurnal publikasi Sulaeman (2014) mendeskripsikan pengertian gaji pokok sebagai imbalan yang diberikan oleh pemberi kerja kepada karyawan, yang penerimaannya bersifat rutin dan tetap setiap bulan walaupun tidak masuk kerja maka gaji akan tetap diterima secara penuh. Gaji pokok merupakan balas jasa yang dibayar secara periodik kepada karyawan yang tetap serta mempunyai jaminan yang pasti.

Indikator upah dalam penelitian ini berdasarkan teori upah menurut As'ad (1998) adalah berupa besaran upah dan kesesuaian upah yang diterima karyawan.

\section{Masa Kerja Karyawan}

Masa kerja merupakan salah satu indikator tentang kecenderungan para karyawan dalam melakukan aktivitas kerja (Siagian, 2012:89), sehingga dapat dikatakan bahwa masa kerja yang lama menunjukkan pengalaman yang lebih dari seseorang dengan rekan kerja yang lain. Menurut jurnal Septiana (2015), senioritas atau masa kerja adalah lamanya seorang karyawan menyumbangkan tenaganya pada perusahaan tertentu. Sejauh mana tenaga dapat mencapai hasil yang memuaskan dalam bekerja tergantung dari kemampuan, kecakapan, dan keterampilan tertentu agar dapat melaksanakan pekerjaannya dengan baik.

Masa kerja merupakan pengalaman individu yang selanjutnya akan menentukan pertumbuhan dalam pekerjaan dan jabatan, serta juga dapat dikatakan sebagai loyalitas karyawan kepada perusahaan. Rentang waktu masa kerja yang cukup sama dengan orang yang memiliki pengalaman yang luas baik hambatan dan keberhasilan.

Indikator masa kerja dalam penelitian ini menurut Siagian (2012:89) adalah lama masa kerja, pengalaman kerja, pengetahuan, dan keterampilan kerja. 


\section{Pengaruh Variabel Pelatihan terhadap Produktivitas Karyawan}

Menurut Karima dkk (2018) dalam jurnal penelitiannya mengemukakan pelatihan merupakan variabel yang mempengaruhi produktivitas. Pada penelitiannya dengan sampel sebanyak 62 karyawan dari total 166 karyawan dan kemudian diteliti dengan analisis regresi menghasilkan hasil yang signifikan berpengaruh positif terhadap produktivitas karyawan. Penelitian lain dilakukan juga sebelumnya oleh Kandou (2012) dalam penelitiannya di PT Air Manado dengan sampel sebanyak 30 karyawan diuji hasil produktivitasnya berdasarkan indikator pelatihan maka menunjukkan produktivitas kerja karyawan akan bertambah atau meningkat secara berarti apabila diberikan pelatihan dan pengembangan karyawan, maka dapat dipastikan produktivitas karyawan akan lebih baik atau meningkat secara signifikan.

Penelitian lain dilakukan juga di Virginia oleh Khaled (2016), mengatakan dalam jurnalnya bahwa efektivitas pelatihan kerja terhadap produktivitas yang diberlakukan pada 230 sampelnya memberikan pengaruh sebanyak 9,8\% terhadap produktivitas karyawan di beberapa sektor dengan 30 perusahaan secara acak.

H1: Pelatihan kerja berpengaruh terhadap produktivitas karyawan

\section{Pengaruh Variabel Upah terhadap Produktivitas Karyawan}

Upah merupakan variabel lain yang dikemukakan beberapa peneliti sebelumnya bahwa variabel tersebut berpengaruh terhadap produktivitas. Menurut Apriyani (2014) dalam jurnal publikasinya mengemukakan bahwa adanya pengaruh yang signifikan terhadap produktivitas karyawan $\mathrm{CV}$ Usaha Makmur Solo, serta berpengaruh sangat kuat pada upah insentif. Penelitian lain didukung oleh Candra (2013) dalam jurnal publikasi yang dikaji melalui penelitian home produksi Jenang Milah Kabupaten Ponorogo menyatakan hasil penelitiannya bahwa upah berpengaruh secara signifikan terhadap produktivitas. Penelitian lain dari Hermanto (2012) mengatakan bahwa tidak ada pengaruh upah terhadap produktivitas.

H2: Upah berpengaruh terhadap produktivitas karyawan

\section{Pengaruh Variabel Masa Kerja terhadap Produktivitas Karyawan}

Karima dkk (2018) dalam jurnal penelitiannya juga mengemukakan masa kerja merupakan variabel yang mempengaruhi produktivitas. Pada penelitiannya diteliti dengan analisis regresi menghasilkan hasil yang signifikan bahwa masa kerja ikut berpengaruh positif terhadap produktivitas karyawan. Begitu juga dengan penelitian Septiana (2015) dalam jurnal publikasi meneliti pengaruh variabel masa kerja, kompensasi, dan pendidikan terhadap motivasi kerja karyawan Dinas Bina Marga Provinsi Jawa Tengah dengan produktivitas kerja sebagai variabel intervening, dari hasil penelitian didapat hasil yang menyatakan bahwa masa kerja secara simultan berpengaruh positif terhadap produktivitas secara langsung.

Hal lain sebelumnya dilakukan oleh Laminia dkk (2008) dengan penelitiannya yang mengkaji hubungan motivasi dan masa kerja dengan Produktivitas karyawan di home industry bahwa tidak terdapat hubungan antara masa kerja dengan produktivitas.

H3: Masa kerja berpengaruh terhadap produktivitas karyawan

\section{Kerangka Pemikiran}

Berdasarkan uraian di atas tersebut maka dibuatkan gambar model di bawah ini:

Gambar 3

Kerangka Penelitian

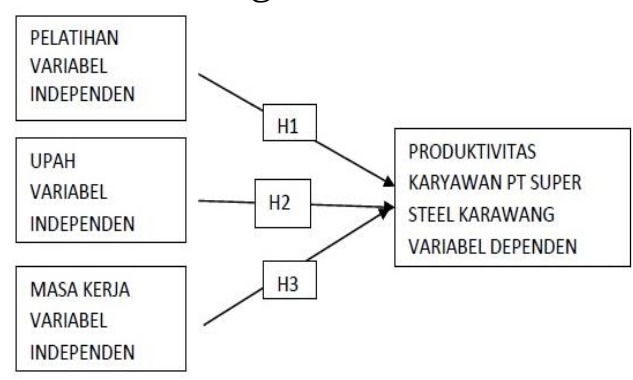

Sumber: Diolah oleh peneliti, 2019 


\section{METODE PENELITIAN Sampel Penelitian}

Penelitian ini bersumber dari populasi di perusahaan PT Super Steel Karawang di tiga perusahaannya yaitu dengan wilayah Cikarang Selatan MM2100 dan dua perusahaan di Surya Cipta Karawang (SSK 2 dan Blanking). Sampel penelitian diambil 201 sampel dari populasi seluruh karyawan baik dari level operator hingga level manajemen. Teknik pengambilan sampel menggunakan teknik sampel Slovin dengan skema random sampling, dengan rumus sampel Slovin berikut:

$$
\begin{aligned}
& n=\frac{N}{1+N e^{2}}, \text { Sampel }=\frac{\text { Populasi }}{1+\text { margin error kuadrat }} \\
& n=\frac{N}{1+N e^{2}}=\frac{403}{1+(403)\left(0.05^{2}\right)} \\
& =200,747 \approx 201 \text { responden }
\end{aligned}
$$

\section{Operasionalisasi Variabel}

Operasional variabel pada penelitian ini dapat dijabarkan sebagai berikut:

\begin{tabular}{|c|c|c|c|}
\hline Variabel & Definisi & Dimensi & Indikator \\
\hline \multirow[t]{3}{*}{$\begin{array}{l}\text { Pelatihan } \\
\text { (X1) }\end{array}$} & \multirow{3}{*}{$\begin{array}{l}\text { Mangkunegara (2011). } \\
\text { memberikan batasan } \\
\text { Pendidikan dan latihan } \\
\text { adalah suatu usaha untuk } \\
\text { meningkatkan } \\
\text { kemampuan teknis, } \\
\text { teoritis, konseptual dan } \\
\text { moral karyawan sesuai } \\
\text { dengan kebutuhan } \\
\text { pekerjaan/jabatan } \\
\text { melalui pendidikan dan } \\
\text { latihan. }\end{array}$} & Instruktur & $\begin{array}{l}\text { 1. Latar Belakang } \\
\text { Pendidikan } \\
\text { 2. Penguasaan Materi } \\
\text { 3. Penyampaian materi } \\
\text { 4. Menanggapi peserta } \\
\text { 5. Cara memotivasi } \\
\text { peserta }\end{array}$ \\
\hline & & Materi & $\begin{array}{l}\text { 1. Kesesuain materi } \\
\text { 2. Manfaat materi } \\
\text { 3. Metode yang } \\
\text { digunakan }\end{array}$ \\
\hline & & Fasilitas & 1. Lokasi \& Alat Bantu \\
\hline $\begin{array}{l}\text { Upah } \\
(X 2)\end{array}$ & $\begin{array}{lr}\text { Sistem } & \text { pembatasan } \\
\text { indikator pengupahan } \\
\left(\text { As'ad, 1998) }^{\prime}\right.\end{array}$ & Benefit & $\begin{array}{l}\text { 1. THP yang diterima } \\
\text { 2. Kepuasaan } \\
\text { karyawan terhadap } \\
\text { benefit } \\
\text { 3. Kepuasan karyawan } \\
\text { terhadap kenaikan } \\
\text { gaji } \\
\text { 4. Kepuasaan } \\
\text { karyawan terhadap } \\
\text { system penggajian } \\
\text { 5. Motivasi }\end{array}$ \\
\hline \multirow[t]{3}{*}{$\begin{array}{l}\text { Masa Kerja } \\
\text { (《3) }\end{array}$} & \multirow{3}{*}{$\begin{array}{l}\text { Menjelaskan Masa Kerja } \\
\text { dapat dikatakan sebagai } \\
\text { Siagian (2012:89) adalah } \\
\text { lama masa kerja, } \\
\text { pengalaman kerja, } \\
\text { pengetahuan dan } \\
\text { keterampilan kerja, } \\
\begin{array}{l}\text { loyalitas karyawan pada } \\
\text { perusahaan }\end{array}\end{array}$} & $\begin{array}{l}\text { Masa Kerja \& } \\
\text { Pengalaman } \\
\text { kerja }\end{array}$ & $\begin{array}{l}\text { 1. Lama Masa kerja } \\
\text { 2. Rasa memiliki dan } \\
\text { mencintai pekerjaan }\end{array}$ \\
\hline & & Pengetahuan & $\begin{array}{l}\text { 1. Pertumbuhan ilmu } \\
\text { dan pengerahuan } \\
\text { karyawan }\end{array}$ \\
\hline & & Pengetahuan & $\begin{array}{l}\text { 1. Mahir menggunakan } \\
\text { alat maupun raw } \\
\text { material } \\
\text { 2. Manfaat } \\
\text { keterampilan }\end{array}$ \\
\hline
\end{tabular}

Tabel 1

Operasional Variabel

Sumber: Diolah oleh peneliti, 2019

\section{Metode Analisis Data}

Metode dalam analisis penelitian ini menggunakan analisis regresi berganda dengan minimum kesalahan $\mathrm{a}=5 \%$. Diambil berdasarkan data primer dari kuesioner dengan skala likert serta sumber data yang bersifat nominal dan ordinal. Setiap indikator pertanyaan diuji realibitas dan validitasnya untuk selanjutnya dianalisis regresi menggunakan aplikasi Minitab 18 dan SPSS 25.

\section{HASIL DAN PEMBAHASAN Hasil Penelitian Karakteristik Responden}

Profil 201 responden terpilih di PT Super Steel Karawang dapat digambarkan sebagai berikut:

Gambar 4

Jenis Status Pekerjaan Responden

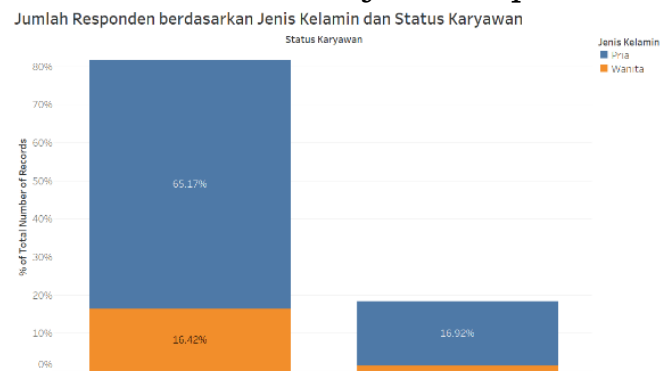

Sumber: Diolah oleh peneliti, 2019

Status karyawan di PT Super Steel Karawang terdiri dari dua jenis, yaitu permanen (tetap) dan kontrak. Responden didominasi oleh karyawan tetap pria dan sisanya adalah karyawan kontrak yang juga didominasi oleh karyawan pria.

\section{Gambar 5}

Jabatan dan Unit Kerja

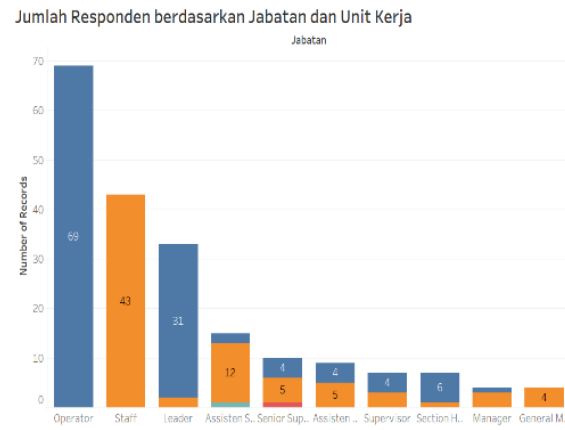

Sumber: Diolah oleh peneliti, 2019 
Tabel 3

Uji Reliabilitas

\begin{tabular}{|c|c|c|}
\hline \multicolumn{3}{|c|}{ Reliability Statistics } \\
\hline Var & Cronbach's Alpha & N of Items \\
\hline X1 & 0.966 & 30 \\
X2 & 0.911 & 30 \\
X3 & 0.926 & 30 \\
Y & 0.882 & 30 \\
\hline
\end{tabular}

Sumber: Diolah oleh peneliti, 2019

Berdasarkan tabel di atas, terdapat total 30 pertanyaan untuk diuji reliabilitas secara keseluruhan dari total variabel $\mathrm{X} 1, \mathrm{X} 2, \mathrm{X} 3$, dan $\mathrm{Y}$ dengan nilai Cronbach's Alpha > 0,6, sesuai dengan metode uji reliabilitas yang kita gunakan sehingga dapat disimpulkan bahwa ralpha masing-masing variabel positif dan lebih besar dari 0,6 maka data dikatakan reliabel sangat baik atau reliabilitas sempurna karena nilai Cronbach's Alpha pada masing masing > 0,9 .

\section{Uji Normalitas}

Data yang baik untuk analisis regresi adalah data yang memiliki residual berdistribusi normal. Residual adalah beda antara $\mathrm{Y}$ hasil pengamatan dengan $Y$ hasil prediksi. Asumsi normalitas pada regresi linear adalah melekat terhadap residualnya, bukan pada data per variabel. Jika asumsi ini tidak dipenuhi, akan menyebabkan keputusan yang diambil tidak tepat. Teknik yang digunakan untuk menguji normalitas data dalam penelitian ini adalah Kolmogorov-Smirnov untuk sampel yang jumlahnya besar $(>200)$ dan secara grafik Q-Q Plot.

Tabel 4

Uji Normalitas

\begin{tabular}{|c|c|c|c|c|c|c|}
\hline \multicolumn{7}{|c|}{ Tests of Normality } \\
\hline & \multicolumn{3}{|c|}{ Kolmogorov-Smirnov ${ }^{2}$} & \multicolumn{3}{|c|}{ Shapiro-Wilk } \\
\hline & Statistic & df & Sig. & Statistic & Df & Sig. \\
\hline TOTAL & .062 & 201 & 054 & 978 & 201 & .003 \\
\hline \multicolumn{7}{|c|}{ a. Lilliefors Significance Correction } \\
\hline
\end{tabular}

Sumber: Diolah oleh peneliti, 2019

Berdasarkan tabel Test of Normality di atas dapat dilihat nilai signifikan yang terdapat pada Kolmogorov-Smirnov adalah 0,054 > 0,05, maka data berdistribusi normal. Untuk uji normalitas, penulis juga menggunakan grafik Normal P-Plot. Tabel tersebut dapat dilihat di bawah ini.

Gambar 9

Tabel Normalitas Tes

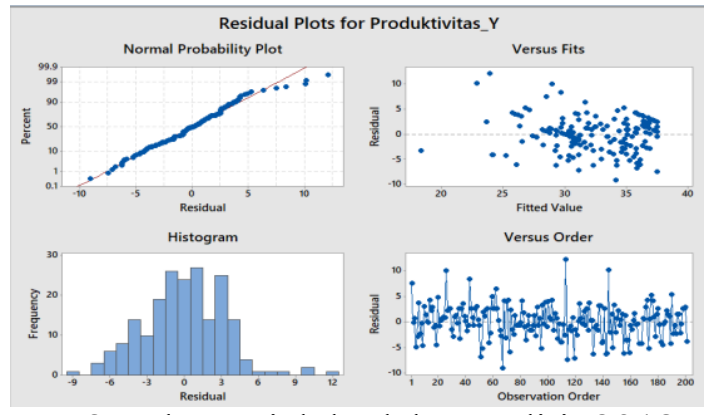

Sumber: Diolah oleh peneliti, 2019

\section{Asumsi Bebas Heteroskedastisitas}

Peneliti menggunakan metode grafik untuk melakukan uji terhadap asumsi homoskedastisitas tersebut. Diagram scatter antara variabel Y prediksi (Fitted Value) dengan variabel residual menunjukan plot menyebar merata di atas dan di bawah sumbu 0 tanpa membentuk pola tertentu, sehingga dapat disimpulkan bahwa pada data penelitian ini tidak terdapat heteroskedastisitas.

\section{Asumsi Bebas Autokorelasi}

Autokorelasi adalah korelasi atau hubungan yang terjadi antar pengamatan dalam satu variabel yang sama. Regresi linear berganda yang dilakukan dengan data yang mengandung autokorelasi akan menghasilkan hasil pengujian hipotesis yang tidak valid. Pengujian autokorelasi dapat dilakukan dengan beberapa teknik, salah satunya yaitu Uji Durbin Watson yang digunakan peneliti dalam studi kasus ini.

Tabel 5

Model Summary

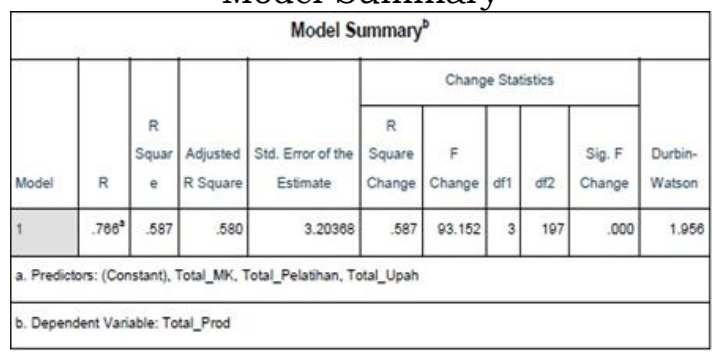

Sumber: Diolah SPSS 25 oleh peneliti, 2019 
Berdasarkan tabel Durbin Watson (a $=5 \%$ ), nilai du dan dl untuk jumlah sampel sebanyak 201 dan jumlah variabel independen sebanyak 3 buah adalah du $=1.739$ dan $\mathrm{dl}=1.799$. Adapun nilai statistik uji $\mathrm{dw}=1,956$ berada di antara rentang du $<\mathrm{DW}<2$ atau rentang $1,739<1,956<2$. sehingga dapat disimpulkan bahwa data tidak memiliki autokorelasi.

\section{Asumsi Bebas Multikolinearitas}

Hasil pengujian asumsi multikolinearitas yang telah dilakukan oleh peneliti dengan syarat nilai Variance Inflation Factor (VIF) lebih dari 10 maka ada indikasi masalah multikolinearitas adalah sebagai berikut: Tabel 6

Coeffisient Multikolineritas

\begin{tabular}{|lrrrrr|}
\hline Coefficients & & & & & \\
Term & Coef & SE Coef & T-Value & P-Value & VIF \\
\hline Constant & 10.64 & 1.47 & 7.24 & 0.000 & \\
Pelatihan_X1 & 0.0918 & 0.0534 & 1.72 & 0.087 & 2.10 \\
upah_X2 & 0.0880 & 0.0963 & 0.91 & 0.362 & 2.10 \\
Masa Kerja_X3 & 1.052 & 0.107 & 9.84 & 0.000 & 1.79 \\
\hline
\end{tabular}

Sumber: Diolah oleh peneliti, 2019

Berdasarkan nilai VIF di atas semua variabel < 10 maka dinyatakan seluruh variabel bebas multikolinearitas.

\section{Pembahasan}

\section{Interpretasi Analisi Regresi}

Berdasarkan analisis regresi linear berganda yang dijalankan pada perangkat lunak Minitab 18, diperoleh output sebagai berikut:

Tabel 7

Analisis Variansi (ANOVA)

\begin{tabular}{|lrrrrr|}
\multicolumn{6}{l}{ Analysis of Variance } \\
Source & DF & Adj SS & Adj MS & F-Value & P-Value \\
\hline Regression & 3 & 2727.01 & 909.00 & 82.40 & 0.000 \\
Pelatihan_X1 & 1 & 32.65 & 32.65 & 2.96 & 0.087 \\
upah_X2 & 1 & 9.22 & 9.22 & 0.84 & 0.362 \\
Masa Kerja_X3 & 1 & 1068.98 & 1068.98 & 96.90 & 0.000 \\
Error & 197 & 2173.23 & 11.03 & & \\
Lack-of-Fit & 146 & 1991.53 & 13.64 & 3.83 & 0.000 \\
Pure Error & 51 & 181.70 & 3.56 & & \\
Total & 200 & 4900.24 & & & \\
\hline
\end{tabular}

Sumber: Diolah Minitab18 oleh peneliti, 2019

Dari uji analisa pada tabel ANOVA diperoleh nilai Fhitung sebesar 82,40 sedangkan Ftabel (a 0,05) untuk $\mathrm{n}=$ $201, \mathrm{df}=\mathrm{n}-2=199$ sebesar 2,65. Jadi $\mathrm{F}$ hitung > dari F tabel (a 0,05) atau 82,40 $>2,65$, dengan tingkat signifikan sebesar 0,000. Karena 0,000 $<0,05$, maka dapat dikatakan dapat disimpulkan bahwa produktivitas karyawan memiliki hubungan linear dengan minimal 1 (satu) variabel bebas ke-1 sampai ke-3.

Berbeda dengan uji $F$ yang dilakukan untuk keseluruhan model, uji $\mathrm{t}$ dilakukan secara parsial untuk menguji hubungan masing-masing variabel bebas terhadap respon. Penelitian ini melibatkan 3 (tiga) variabel bebas, dengan masing masing kesimpulan yaitu:

Tabel 8

Hasil Uji Parsial

\begin{tabular}{|l|l|l|}
\hline $\begin{array}{l}\text { Var } \\
\text { Independent }\end{array}$ & P-Value & Hasil \\
\hline $\begin{array}{l}\text { X1 } \\
\text { (Pelatihan) }\end{array}$ & $0,087>0,05$ & $\begin{array}{l}\text { Tidak berpengaruh } \\
\text { terhadap produktivitas }\end{array}$ \\
\hline $\begin{array}{l}\text { X2 } \\
\text { (Upah) }\end{array}$ & $0,362>0,05$ & $\begin{array}{l}\text { Tidak berpengaruh } \\
\text { terhadap produktivitas }\end{array}$ \\
\hline $\begin{array}{l}\text { X3 } \\
\text { Masa Kerja) }\end{array}$ & $0,000<0,05$ & $\begin{array}{l}\text { Berpengaruh terhadap } \\
\text { produktivitas }\end{array}$ \\
\hline
\end{tabular}

\section{Pemilihan Model Regresi Terbaik}

Berdasarkan hasil uji $\mathrm{t}$ yang telah dilakukan peneliti pada model sebelumnya, masih terdapat variabel bebas yang menunjukan nilai $\mathrm{P}$-value yang lebih besar dari nilai a $(0,05)$, sehingga dilakukan evaluasi model dengan menggunakan metode backward elimination procedure. Metode ini akan menyeleksi variabel bebas yang tidak berpengaruh dengan mengeluarkannya satu per satu dari model semula. Pada tahap pertama, variabel bebas paling tidak berpengaruh atau tidak signifikan dikeluarkan dari model. Proses akan berhenti saat tidak ada lagi variabel bebas tidak signifikan yang tersisa.

Tabel 9

Analisis Variansi Backward Eliminasi (ANOVA)

\begin{tabular}{|lrrrrr|}
\hline \multicolumn{6}{l}{ Analysis of Variance } \\
Source & DF & Adj SS & Adj MS & F-Value & P-Value \\
\hline Regression & 2 & 2717.79 & 1358.89 & 123.28 & 0.000 \\
Pelatihan_X1 & 1 & 68.59 & 68.59 & 6.22 & 0.013 \\
Masa Kerja_X3 & 1 & 1278.66 & 1278.66 & 116.00 & 0.000 \\
Error & 198 & 2182.45 & 11.02 & & \\
Lack-of-Fit & 147 & 2000.75 & 13.61 & 3.82 & 0.000 \\
Pure Error & 51 & 181.70 & 3.56 & & \\
Total & 200 & 4900.24 & & & \\
\hline
\end{tabular}

Sumber: Diolah Minitab18 oleh peneliti, 2019 
Melalui proses eliminasi backward maka didapat hasil dua variabel tersisa merupakan variabel independen yang masing-masing variabel pelatihan berpengaruh terhadap produktivitas, begitu juga dengan variabel masa kerja dengan nilai $P$-Value masing-masing < 0,05 .

Tabel 10

Model Summary

\begin{tabular}{|c|c|c|c|}
\hline \multicolumn{4}{|c|}{ Model Summary } \\
\hline S & $R-s q$ & R-sq(adj) & R-sq(pred) \\
\hline 3.32001 & $55.46 \%$ & $55.01 \%$ & $53.56 \%$ \\
\hline
\end{tabular}

Sumber: Diolah Minitab18 oleh peneliti, 2019

Merujuk pada nilai koefisien masing-masing variabel pada persamaan regresi, dapat diinterpretasikan bahwa setiap penambahan skor kepuasan karyawan terhadap pelatihan sebesar satu satuan, maka rataan skor produktivitas karyawan di PT Super Steel Karawang akan naik sebesar 0,1158 . Selain itu, setiap penambahan skor masa kerja karyawan sebesar satu satuan, maka skor produktivitas karyawan di PT Super Steel Karawang akan naik sebesar 1,084. Nilai R-square (adj) sebesar 55,01\% memiliki makna bahwa variabel pelatihan dan masa kerja dapat menjelaskan keragaman dari variabel produktivitas karyawan sebesar $55,01 \%$ dan sisanya dapat dijelaskan oleh variabel lain yang tidak ada di dalam model.

Berdasarkan hasil output pada tabel di atas, maka dapat diidentifikasikan bahwa persamaan regresi sebagai berikut:

$$
\begin{aligned}
& \text { Regression Equation } \\
& \text { Produktivitas_Y }=10.53+0.1158 \text { Pelatihan_X1 }+1.084 \text { Masa Kerja_X3 }
\end{aligned}
$$

Sumber: Peneliti, Output Minitab 18, 2019

\section{Pengaruh Pelatihan terhadap Produktivitas}

Hasil analisis menunjukkan pengaruh pelatihan berpengaruh positif kepada produktivitas karyawan sesuai dengan teori Karima dkk (2018) yang menyatakan bahwa ada pengaruh positif dari pelatihan terhadap produktivitas.
Hal tersebut juga diperkuat oleh pendukung teori sebelumnya Kandou (2012), Hermanto (2012), Nur'aini (2012), dan Satria (2013), serta Wijaya (2018), Khaled (2016), dan Nassazi (2013) yang mendukung pernyataan peneliti bahwa ada pengaruh pelatihan terhadap produktivitas karyawan. Menunjang penelitian penelitian sebelumnya maka dapat dibuktikan secara empiris dalam penelitian ini bahwa pelatihan berpengaruh secara positif terhadap produktivitas, dengan melibatkan indikator penyampaian materi, kesiapan instruktur serta fasilitas pelatihan kerja.

Pelatihan telah dibuktikan dengan empiris bahwa terdapat pengaruh terhadap peningkatan produktivitas, cukup besar pengembangan pelatihan di perusahaan PT Super Steel karawang.

\section{Pengaruh \\ Produktivitas}

Upah

terhadap

Berdasarkan hasil penelitian yang diteliti dengan besaran sampel 201 menghasilkan penolakan hipotesis yaitu tidak adanya pengaruh upah terhadap produktivitas karyawan. Hal ini menolak penelitian-penelitian sebelumnya yang mendukung adanya pengaruh upah terhadap produktivitas seperti yang diutarakan oleh Apriyani (2014) bahwa ada pengaruh upah insentif terhadap produktivitas, juga menurut Candra (2013) yang juga menyatakan bahwa ada pengaruh upah terhadap produktivitas ini berlawanan dengan hasil penelitian. Penelitian ini berhasil menguatkan penelitian dari Hermanto (2012) dan Wijaya (2018) yang mengatakan bahwa tidak ada pengaruh upah terhadap produktivitas. Sehingga penelitian ini memperoleh hasil tidak ada pengaruh variabel upah tehadap produktivitas karyawan. Hal ini membuktikan bahwa besar kecilnya upah yang diterima karyawan tidak berpengaruh terhadap produktivitas karyawan begitu juga dengan indikatornya mengikuti kesesuaian upah mengikuti aturan kerja juga tidak berpengaruh dalam peningkatan produktivitas. 


\section{Pengaruh Masa Kerja terhadap Produktivitas}

Hasil penelitian ini memprediksi adanya pengaruh positif terhadap masa kerja terhadap produktivitas. Penelitian ini menolak penelitian Laminia dkk (2008) dengan penelitiannya yang menghasilkan tidak adanya hubungan masa kerja terhadap produktivitas kerja di home industry yang ditelitinya. Namun hasil penelitian dalam sampel yang dilakukan oleh peneliti ini mendukung pernyataan Karima, dkk (2018) yang mengemukakan masa kerja merupakan variabel yang mempengaruhi produktivitas. Hal ini juga didukung penelitian sebelumnya oleh Septiana (2015) mengatakan ada pengaruh variabel masa kerja dengan produktivitas kerja karyawan. Sehingga dapat berpengaruh positif secara linier, yaitu semakin lama kerja karyawan semakin besar produktivitasnya dengan melibatkan beberapa faktor indikator diantaranya loyalitas selama bekerja kemampuan kerja, keterampilan, dan pengalaman kerja.

\section{KESIMPULAN \\ Simpulan}

Dari hasil penelitian dapat disimpulkan bahwa terdapat pengaruh pelatihan terhadap produktivitas karyawan yang dinyatakan bahwa pelatihan (X1) berpengaruh terhadap produktivitas secara positif, terdapat pengaruh masa kerja terhadap produktivitas karyawan yang dinyatakan bahwa masa kerja (X3) berpengaruh terhadap produktivitas secara positif, namun tidak terdapat pengaruh atas upah (X2) yang diterima terhadap produktivitas karyawan secara signifikan di PT Super Steel Karawang.

\section{Saran}

Perusahaan diharapkan dapat meningkatkan kegiatan yang menunjang produktivitas dengan menambah pelatihan kerja, memberi penghargaan lain agar loyalitas karyawan bertambah dan mampu meningkatkan produktivitas, serta melihat variabel lain sebagai pendukung peningkatan produktivitas.

\section{DAFTAR PUSTAKA}

Apriyani, F. 2014. Pengaruh upah kerja pengalaman kerja dan disiplin kerja terhadap produktivitas. Jurnal Publikasi Universitas Muhammadiyah Surakarta.

As'ad, M. 1998. Psikologi industri, Yogyakarta: Library.

Badan Pusat Statistik. 2008. Analisis Perkembangan Statistik Ketenagakerjaan (Laporan Sosial Indonesia 2007). Jakarta: Badan Pusat Statistik

Candra, Safrida Riana. 2013. Pengaruh upah kerja terhadap produktivitas karyawan pada home produksi jenang "Milah" di kabupaten Ponorogo. Jurnal Equilibrium 156 1 (2).

Hariandja, Marihot Tua Efendi. 2002. Manajemen sumber daya manusia pengadaan, pengembangan, pengkompensasian dan peningkatan produktivitas karyawan. Review Hal. Jakarta: Grasindo.

Herjanto, E. 2007. Manajemen Operasi. Jakarta: PT Grasindo.

Hermanto, Bambang. 2012. Pengaruh prestasi pelatihan, motivasi, dan masa kerja terhadap produktivitas teknisi PT Nissan Yogyakarta, Solo dan Semarang. Jurnal Publikasi Universitas Negeri Yogyakarta.

Karima, A. N., Nursyamsi, I., Umar, F. 2018. The effect of the work, training and motivation to employee productivity at pt. Bank sulselbar major branch of makassar. Hasanuddin Journal of Applied Business and Entrepreneurship, 1(4):83-95.

Kandou, E. E. 2019. Pengaruh pelatihan dan pengembangan karyawan terhadap produktivitas kerja karyawan. Jurnal Publikasi Ekonomi dan Bisnis.

Kemdikbud. 2018. Kamus Besar Bahasa Indonesia, edisi 5. Jakarta: Balai Pustaka. 
Khaled. 2016. The Effectiveness of the training programs on employee performance. International Journal of Business and Management Review, 4 (9):1-23.

Laminia, D. 2008. Hubungan motivasi dan masa kerja dengan produktivitas karyawan di home industry. The Indonesian Journal of Occupational Safety and Health, 7 (2):241-248

Mangkunegara. 2011. Manajemen sumber daya perusahaan. Bandung: PT Remaja Rosdakarya.

Nassazi, A. 2013. Effects of training on employee performance. Vaasan Ammattikorkeakoulu International Bussines Economisc and Tourism.

Nawawi, H. H. 2003. Manajemen sumber daya manusia untuk bisnis yang kompetitif, cetakan ke-7. Yogyakarta: Gadjah Mada University Press.

Nur'aini. 2012. Variabel-variabel yang mempengaruhi produktivitas kerja pada perusahaan Holand Bakery Pekanbaru. Jurnal Publikasi Universitas Islam Sultan Syarif Kasim.

Rosadi, D. 2005. Modul Praktikum Komputasi Statistika: Pengantar Analisa Statistika dengan R. Yogyakarta: Program Studi Statistika FMIPA UGM.

Satria, R. O. 2013, pengaruh motivasi dan pelatihan terhadap kompetensi kerja serta implikasinya pada produktivitas karyawan dinas perhubungan kota Bandung. Jurnal Ekonomi, Bisnis \& Entrepreneurship, 7 (2):74-83.

Septiana, V. A. 2015. Pengaruh variabel masa kerja, kompensasi dan pendidikan terhadap motivasi kerja karyawan dinas bina marga dengan produktivitas sebagai variabel intervening. Journal of Management, 1(1).

Simamora, H. 2004. Manajemen sumber daya manusia, edisi ketiga. Yogyakarta: STIE YKPN.

Siagian, S. 2012. Manajemen sumber daya manusia, edisi kedua. Yogyakarta: STIE YKPN.

Soedjardi. $2008 . \quad$ Hukum ketenagakerjaan di Indonesia. Yogyakarta: Pustaka Yustisia.

Sulaeman, A. 2014. Pengaruh upah dan pengalaman kerja terhadap produktivitas karyawan kerajinan ukiran Kabupaten Subang. Trikonomika, 13 (1):91-100.

Wijaya, M. A. 2018. Pengaruh pelatihan insentif dan lingkungan kerja terhadap produktivitas karyawan Bank DKI Cabang Otista. Jurnal Publikasi IPWIJA. 